\title{
Micronucleus Assay of Buccal Mucosa Cells in Hairdressers: The Importance of Occupational Exposure
}

\author{
Asian Pac J Cancer Prev, 20 (5), 1297-1298
}

\section{Dear Editor}

I read the recent paper of da Farhadi et al., (2018) published in Asian Pacific Journal of Cancer Prevention entitled "Micronucleus assay of buccal mucosa cells in hairdressers: the importance of occupational exposure" with much interest. In this article, the authors were able to detect high frequencies of micronuclei in hairdressers when compared to matched controls. However, this study has some questions that must be clarified for better understanding the paper.

First, it is important to mention that Papanicolaou technique is not suitable when evaluating the micronucleus assay in buccal mucosa cells since it is not specific for nucleic acids. Feulgen-Fast Green method has been considered as the best way for this purpose (Bonassi et al., 2011). Considering the lack of DNA specificity when staining Papanicolaou technique, high micronuclei frequencies will be detected due to the identification of cell structures rather than micronucleus, such as keratohyalin granules or bacteria (Bonassi et al., 2011). This may explain the high number of micronucleus presented in Table 1 (mean of 16 micronucleated cells in hairdressers and 8 micronucleated cells in the control group). Following the rationale, Figure 1 illustrates some cellular structures that are not categorized as micronucleus. To date, there are some established criteria for identifying the micronucleus, as follows: intact main nucleus and cytoplasm; shape round or oval; separated from the main nucleus; diameter between $1 / 3$ to $1 / 6$ of the main nucleus; same staining and texture as that found in the main nucleus; and the same focal plane from the main nucleus (Bolognesi et al., 2013).

Another question refers to the total number of cell evaluated. It has been established by the Micronucleus Assay Guidelines, that at least 2,000 cells per volunteer must be performed when evaluating the micronucleus assay in buccal mucosa cells (Torres-Bugarin et al. 2014). In this study, a total of 500 cells were evaluated for each sample. Moreover, the authors compare the incidence of micronucleus and working time in Table 2. Although no significant statistically differences were noticed $(p=0.14)$, the authors state that "in this study appears to indicate that more working time has moderative effects on $\mathrm{MN}$ frequency according to Cohen interpretation system". This needs further clarification.

Finally, Tolbert et al., (1992) included some metanuclear changes indicative of cytotoxicity when analyzing micronucleus assay in buccal mucosa cells, such as pyknosis, karyolysis and karyorrhexis. The approach is very important because cytotoxicity is a confounding factor for mutagenesis (Vasquez, 2010). For example, if cytotoxicity is increased the micronucleus frequency decreased automatically. Therefore, it would be interesting to know if and to what extent, hairdressers present cytotoxicity increased. Such information is very important for understanding the incidence of micronucleus in buccal mucosa cells, as well as to identify if the levels of exposure are able to induce cellular death. By comparison, a study published by our research group has demonstrated that oral mucosa cells from hairdressers presented high frequencies of karrhyorexis, pyknosis and karyolysis (Carlin et al., 2013).

I hope that such comments are useful for better understanding the paper investigating cytogenetic damage on oral mucosa cells from hairdressers.

\section{Conflict of Interest Statement}

None declared.

\section{Acknowledgments}

DAR is a recipient of CNPq (Conselho Nacional de Desenolvimento Cientifico e Tecnologico) productivity fellowship.

\section{References}

Bolognesi C, Knasmueller S, Nersesyan A, Thomas P, Fenech M (2013). The HUMNxl scoring criteria for different cell types and nuclear anomalies in the buccal micronucleus cytome assay - an update and expanded photogallery. Mutat Res, 753,100-13.

Bonassi S, Coskun E, Ceppi M, et al (2011). The HUman MicroNucleus project on eXfoLiated buccal cells $(\mathrm{HUMN}(\mathrm{XL}))$ : the role of life-style, host factors, occupational exposures, health status, and assay protocol. Mutat Res, $\mathbf{7 2 8}$, 88-97.

Carlin V, Fracalossi AC, Miranda SR, et al (2013). Chromosome breakage and cellular death are induced in oral epithelial cells of hairdressers: a preliminary study. Toxicol Mech Methods, 23, 108-12.

Farhadi S, Jolehar M, Safapour F (2018). Micronucleus assay of buccal mucosal cells in hairdressers: The importance of occupational exposure. Asian Pac J Cancer Prev, 19, 2131-4.

Tolbert PE, Shy CM, Allen JW (1992). Micronuclei and other nuclear anomalies in buccal smears: methods development. Mutat Res, 271, 69-77.

Torres-Bugarín O, Zavala-Cerna MG, Nava A, Flores-García A, Ramos-Ibarra ML (2014). Potential uses, limitations, and

Asian Pacific Journal of Cancer Prevention, Vol 20

1297 
Daniel Araki Ribeiro

basic procedures of micronuclei and nuclear abnormalities in buccal cells. Dis Markers, 2014, 956835.

Vasquez MZ (2010) Combining the in vivo comet and micronucleus assays: a pratical approach to genotoxicity testing and data interpretation. Mutagenesis, 25,187-99.

\section{Daniel Araki Ribeiro*}

Federal University of Sao Paulo, Brazil. *For Correspondence: daribeiro@unifesp.br 